\title{
Analysis of Aspergillus mycotoxins by gas chromatography using fused silica capillary column
}

\author{
Tetsuhisa GoTo*1, Masami MATSUI*2, and Takaharu KITSUWA*3 \\ 後藤哲久*1, 松居正巳*2, 檑和丘陽*3：Aspergillus の産生するマイコトキシンの \\ ヒューズドシリカキャピラリーカラムガスクロマトグラフィーによる分析
}

\begin{abstract}
Summary
Six mycotoxins, aflatoxins $\left(\mathrm{AFB}_{1}, \mathrm{AFB}_{2}, \mathrm{AFG}_{1}, \mathrm{AFG}_{2}\right)$, cyclopiazonic acid (CA) and kojic acid (KA) which produced by Aspergillus flavus group species were analyzed by GC without chemical derivatization. The GC system contains fused silica capillary column (DB-5, $0.25 \mathrm{~mm}$ i.d. $\times 10 \mathrm{~m}$ ) and capillary on-column injector. Either FID or MS could be used as a detector. The analysis was highly reproducible and the detection limit of these mycotoxins by GC.FID were $1 \mathrm{ng}$ for $\mathrm{AFB}_{1}$ and $\mathrm{AFB}_{2}, 2 \mathrm{ng}$ for $\mathrm{AFG}_{1}$ and $\mathrm{AFG}_{2}, 0.5 \mathrm{ng}$ for $\mathrm{CA}$ and $1 \mathrm{ng}$ for $\mathrm{KA}$.
\end{abstract}

For the analysis of mycotoxins, gas chromatography (GC), thin-layer chromatography (TLC) and high-performance liquid chromatography (HPLC) are commonly used depending on the kind of mycotoxin. Aflatoxins (AFs), a group of mycotoxins produced by Aspergillus flavus group species, are analyzed either by TLC or HPLC but GC has never been successfully applied because of the stability by heat. However, GC system has improved very much and in 1981 Friedli $^{1)}$ showed that $\mathrm{AFB}_{1}$, the most toxic $\mathrm{AF}$, could be analyzed by GC without any chemical derivatization. Subsequently, Trucksess et al. ${ }^{2)}$ and Rosen et al. ${ }^{3)}$ reported that $A F B_{1}$ or mixture of $A F B_{1}$ and $A F B_{2}$ in contaminated peanuts could be detected by $\mathrm{GC}$ with mass spectrometer as a detector. Recently, we reported that not only $\mathrm{AFB}_{1}$ but also $\mathrm{AFB}_{2}, \mathrm{AFG}_{1}$ and $\mathrm{AFG}_{2}$ (all 4 compounds often detected from naturally contaminated agricultural products), could be analyzed by GC using either flame ionization detector (FID) or mass spectrometer (MS)4). Aspergillus flavus group species sometimes produce mycotoxins other than AFs, such as cyclopiazonic acid (CA) and kojic acid (KA). CA was a known

*1 National Food Research Institute, Ministry of Agriculture, Forestry and Fisheries (Kannondai, Tsukuba, Ibaraki 305)

農林水産省食品総合研究所（テ305つくば市観音台2-1-2）

Current address: National Research Institute of Vegetable, Ornamental Plants and Tea, Ministry of Agriculture, Forestry and Fisheries (Kanaya, Shizuoka 428)

農林水産省野菜・茶業試験場（开428 静岡県榛原郡金谷町金谷2769）

*2 Tsukuba Analytical Application Laboratory, Shimadzu Co. (3-17-1, Azuma, Tsukuba, Ibaraki 305) 島津製作所筑波分析センター（テ305つくば市吾妻3-17-1)

*3 Tokyo Analytical Application Laboratory, Shimadzu Co. (1-63-1, Shibazaki, Chofu, Tokyo 182) 島津製作所東京分析センター（テ182 調布市柴崎1-63-1） 

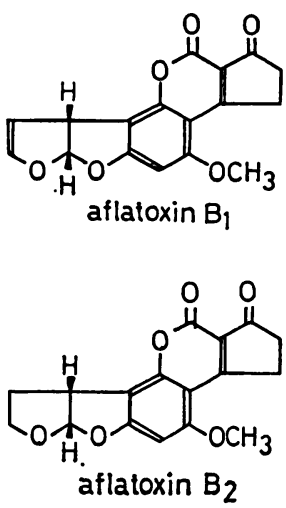
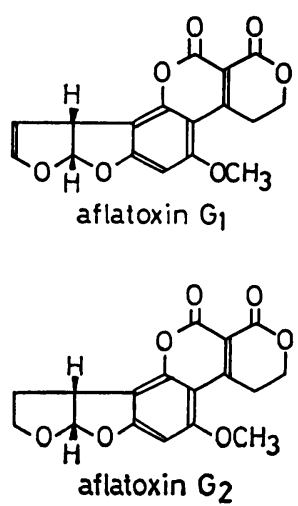

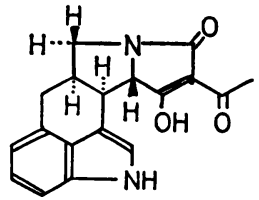

cyclopiazonic acid<smiles>O=c1cc(CO)occ1O</smiles>

kojic acid

Fig. 1. Structures of mycotoxins.

neurotoxic mycotoxin ${ }^{5)}$ and showed mutagenicity for Salmonella typhimurium TA98 and TA100 in the Ames assay ${ }^{6)}$. KA also showed weak acute toxicity ${ }^{7)}$ and mutagenicity for Bacillus subtilis in the Rec assay ${ }^{8)}$. The analysis of CA is usually carried out by normal phase HPLC ${ }^{9}$, reversed phase HPLC ${ }^{10)}$ and $\mathrm{TLC}^{11)}$ and $\mathrm{KA}$ can be analyzed by HPLC ${ }^{12)}$ and GC with chemical derivatization ${ }^{13)}$. $\mathrm{CA}$ and $\mathrm{KA}$ are often produced by aflatoxigenic fungi, so simultaneous analysis for six mycotoxins (Fig. 1), $A F B_{1}, A_{F B}, A_{1} G_{1}, A_{F}, C A$ and KA, was desired. For this purpose, we studied basic conditions for the analysis of these six mycotoxins by GC without chemical derivatization using fused silica capillary column and capillary on-column injector.

\section{Materials and Methods}

Chemicals Standard AFs were purchased from Makor Chemical Co. (Jerusalem, Israel), CA and KA were purchased from Sigma Chem. Co. (MO, USA), and cholestanol (internal standard) was purchased from Tokyo Kasei Co. (Tokyo, Japan). All other solvents and chemicals were either reagent grade or better and used without further purifications. AFs and CA were dissolved in benzene-acetonitrile $(98: 2)$ and $\mathrm{KA}$ was dissolved in methanol. All mycotoxins were mixed and diluted before use.

Gas chromatograph and mass spectrometer ${ }^{4)}$ Shimadzu model GC15 A gas chromatograph (Kyoto, Japan) with FID and Shimadzu Chromatopac C-R4A chromatogram integrator was used for GC-FID analysis. Shimadzu model QP1000A mass spectrometer with GC15A gas chromatograph and PAC200 mass spectra data processing system was used for GC-MS. The ionization voltage was $70 \mathrm{eV}$, ionization current was $60 \mu \mathrm{A}$ and temperatures of ion source and transfer line from $\mathrm{GC}$ to $\mathrm{MS}$ were $250^{\circ} \mathrm{C}$ and $320^{\circ} \mathrm{C}$ respectively. For both $\mathrm{GC}$ and GC-MS, an OC-9 capillary on-column injector was used for sample injection. Fused silica capillary column with chemically bonded five per cent phenylmethyl silicon liquid phase was used (DB-5, $0.25 \mathrm{~mm}$ i.d., J \& W, CA, USA), and the column was directly inserted to ionizing chamber. 


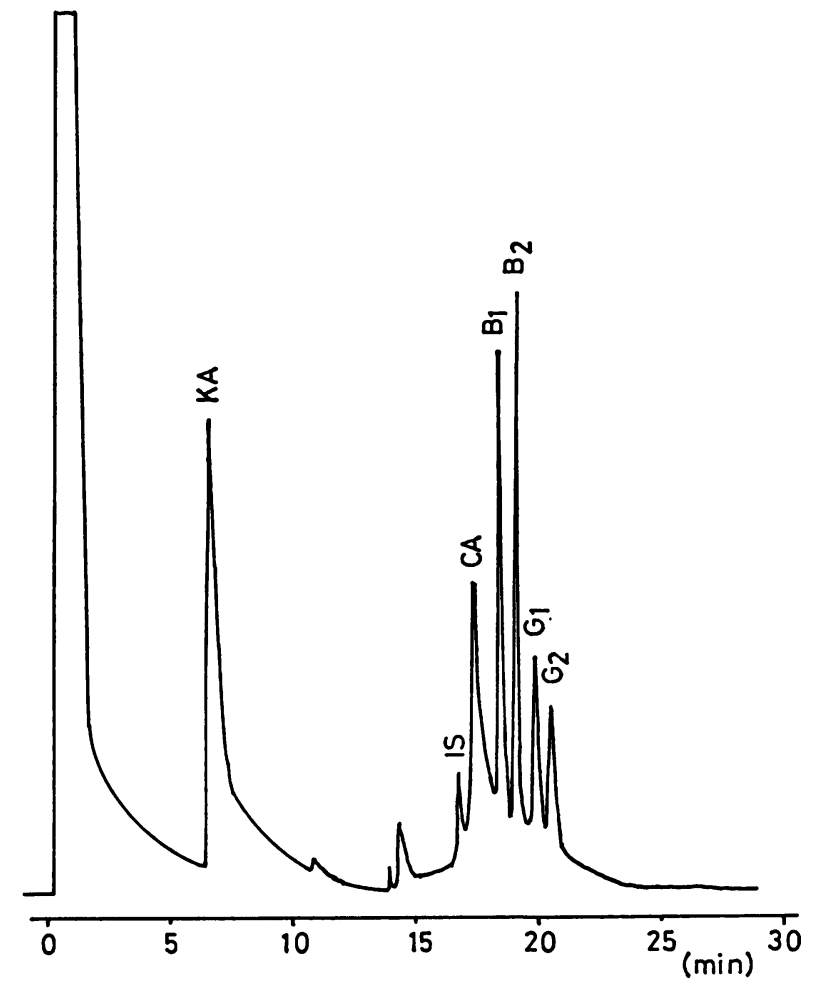

Fig. 2. Chromatogram of mycotoxins by GC.FID. Sample: KA $100 \mathrm{ng}, \mathrm{CA} 20 \mathrm{ng}, \mathrm{AFB}_{1}$ $25 \mathrm{ng}, \mathrm{AFB}_{2} 25 \mathrm{ng}, \mathrm{AFG}_{1} 50 \mathrm{ng}, \mathrm{AFG}_{2} 50 \mathrm{ng}$, Cholestanol $2 \mathrm{ng}$. Column: DB-5, $0.25 \mathrm{~mm}$ i.d. $\times 10 \mathrm{~m}$. Temp. program: $50-300^{\circ} \mathrm{C}, 15^{\circ} \mathrm{C} / \mathrm{min}$.

\section{Results and Discussion}

Analytical conditions Only capillary on-column type injector could successfully introduce samples to the column and no other injector, such as the usual sprit or spritless type injector could introduce samples to the column. The initial temperature of column and injector must be lower than $60^{\circ} \mathrm{C}$ to prevent broadening of peaks. A longer column helped the separation between AFs but reduced the sensitivity. Rapid heating and a high flow rate of carrier gas $(\mathrm{He})$ were required to increase sensitivity, especially for $\mathrm{AFG}_{1}$ and $\mathrm{AFG}_{2}$. Therefore, the initial and final temperatures were set at 50 and $300^{\circ} \mathrm{C}$ respectively and the rate of heating was set at 15 or $20^{\circ} \mathrm{C} / \mathrm{min}$ (Fig. 2). The flow rate of carrier gas was $4 \mathrm{ml} / \mathrm{min}$ for $\mathrm{GC}$ and $2 \mathrm{ml} / \mathrm{min}$ for GC-MS.

Determination of mycotoxins As shown in Table 1 , when cholestanol was used as an internal standard for GC-FID analysis, the standard deviation for all six mycotoxins was less than 0.05 and these values were very good to considering the chemical nature and heat stability of these mycotoxins. The relative sensitivity of these mycotoxins to compare to cholestanol (internal standard) were also shown in Table 1. The sensitivity of these six mycotoxins were not so high to compare to cholestanol probably because of the high contents of oxygen in the 
Table 1. Reproducibility of analysis and relativity sensitivity with internal standard*1

\begin{tabular}{cllcccc}
\hline No. of analysis & $\mathrm{AFB}_{1}$ & $\mathrm{AFB}_{2}$ & $\mathrm{AFG}_{1}$ & $\mathrm{AFG}_{2}$ & $\mathrm{CA}$ & $\mathrm{KA}$ \\
\hline 1 & $1.00^{* 2}$ & 1.08 & 0.33 & 0.35 & 1.045 & 0.617 \\
2 & 1.09 & 1.15 & 0.32 & 0.35 & 1.068 & 0.539 \\
3 & 1.02 & 1.08 & 0.31 & 0.36 & 1.129 & 0.611 \\
4 & 1.00 & 1.08 & 0.32 & 0.36 & 1.004 & 0.528 \\
5 & 1.07 & 1.12 & 0.31 & 0.34 & 1.018 & 0.600 \\
Average & 1.036 & 1.098 & 0.318 & 0.352 & 1.053 & 0.579 \\
SD & 0.042 & 0.036 & 0.008 & 0.008 & 0.049 & 0.042 \\
Sensitivity*3 & 0.084 & 0.089 & 0.025 & 0.026 & 0.209 & 0.104 \\
\hline
\end{tabular}

${ }^{* 1}$ : Cholestanol $(2 \mu \mathrm{g} / \mathrm{ml})$ was used as internal standard.

*2: Ratio of peak area of sample against that of internal standard.

$\mathrm{AFB}_{1} 25 \mathrm{ng}, \mathrm{AFB}_{2} 25 \mathrm{ng}, \mathrm{AFG}_{1} 25 \mathrm{ng}, \mathrm{AFG}_{2} 25 \mathrm{ng}, \mathrm{CA} 10 \mathrm{ng}, \mathrm{KA} 20 \mathrm{ng}$.

${ }^{* 3}$ : Ratio of area counts of the equal weight of sample and cholestanol.

molecule (Fig. 1). The minimum quantification limits of these six mycotoxins by our GCFID system were $1 \mathrm{ng}$ for $\mathrm{AFB}_{1}$ and $\mathrm{AFB}_{2}, 2 \mathrm{ng}$ for $\mathrm{AFG}_{1}$ and $\mathrm{AFG}_{2}, 0.5 \mathrm{ng}$ for $\mathrm{CA}$, and $1 \mathrm{ng}$ for KA. These mycotoxins were also detected by GC-MS to confirm the structures. These six mycotoxins present relatively strong $\mathrm{M}^{+}$ion ${ }^{14)}$, so they could be analyzed with high sensitivity by GC-MS, especially by mass fragment chromatography. The minimum detection limit of these mycotoxins by mass spectrography, KA $\left(\mathrm{M}^{+} 142\right), \mathrm{CA}$ (336), $\mathrm{AFB}_{1}(312)$, $\mathrm{AFB}_{2}(314), \mathrm{AFG}_{1}(328)$, and $\mathrm{AFG}_{2}(330)$ were $0.5 \mathrm{ng}, 0.1 \mathrm{ng}, 0.3 \mathrm{ng}, 0.3 \mathrm{ng}, 1 \mathrm{ng}$, and $1 \mathrm{ng}$ respectively. The sensitivity of mass framgent chromatography was about 10 to 100 times higher than GC-FID depending on the analysis conditions of mass spectrometer.
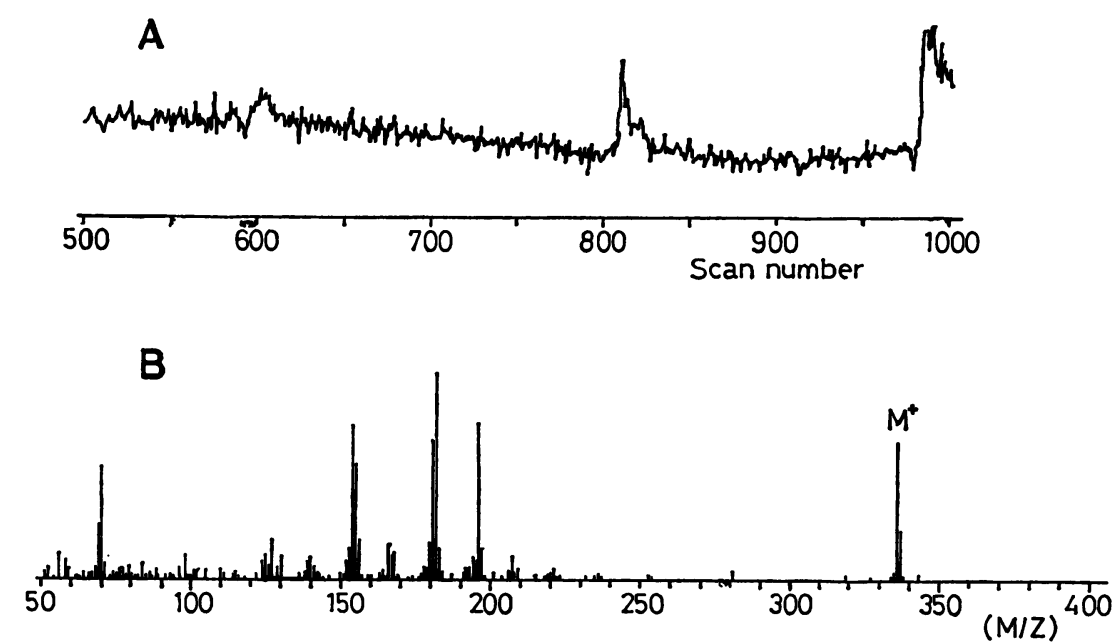

Fig. 3. Mass chromatogram and mass spectrum of $\mathrm{CA}$ in the extract of liquid cultured medium of CA producer.

A. Total ion chromatogram. Scan number: 500 to 1000 ; scan speed: $1 \mathrm{scan} / \mathrm{sec}$; scan range: $50-400 \mathrm{M} / \mathrm{Z}$.

B. Mass spectrum of CA. Scan number: 810-816.

Sample were prepared to following the method described in ref. 9. Conditions of GC were same at the case of Fig. 2. 
The extract of cultured medium of aflatoxigenic fungus was already analyzed ${ }^{4)}$ and this time the extract of liquid culture medium ${ }^{5)}$ of CA producing fungus was analyzed by GC-MS and CA was detected (Fig. 3). This results clearly showed that these mycotoxins produced by Aspergillus flavus group species could be simultaneously analyzed by using GC with fused silica capillary column and capillary on-column sample injector.

\section{References}

1) Friedli, F.: J. High Resolut. Chromatogr. Commun., 4, 495 (1981).

2) Trucksess, M. W., Brumley, W. C., Nesheim, S.: J. Assoc. Off. Anal. Chem., 67, 973 (1984).

3) Rosen, R. T., Rosen, J. D., DiProssino, V. P.: J. Agric. Food Chem., 32, 276 (1984).

4) Goto, T., Matsui, M., Kitsuwa, T.: J. Chromatogr., 447, 410 (1988).

5) Wilson, B. J., Wilson, C. H.: Science, 144, 177 (1964).

6) Sorenson, W. G., Tucker, J. D., Simpson, J. P.: Appl. Environ. Microbiol., 47, 1355 (1984).

7) Friedman, T. E.: Science, 80, 34 (1934).

8) Manabe, M., Goto, T., Tanaka, K., Matsuura, S.: Rept. Natl. Food Res. Inst., 38, 115 (1981). (in Japanese with English abstract).

9) Goto, T., Shinshi, E., Tanaka, K., Manabe, M.: Agric. Biol. Chem., 51, 2581 (1987).

10) Lansden, J. A.: J. Assoc. Off. Anal. Chem., 67, 728 (1984),

11) Dorner, J.W.: Appl. Environ. Microbiol., 46, 1435 (1983).

12) Manabe, M., Shinshi, E., Goto, T., Misawa, S., Tanaka, T., Matsuura, S.: Shoken, 10, 146 (1984). (in Japanese)

13) Manabe, M., Shinshi, E., Goto, T., Tanaka, K., Misawa, Y.: Shoken, 14, 183 (1988). (in Japanese)

14) Cole, R. J., Cox, R. H.: "Handbook of Toxic Fungal Metabolites" pp. 1-937 (1981), Academic Press, New York. 